\title{
Involuntary agent constructions are not directly linked to reduced transitivity
}

\author{
Stefanie Fauconnier \\ University of Leuven
}

\begin{abstract}
This paper investigates the morphosyntactic encoding of involuntary agent constructions (IACs), where a patient is affected by an involuntarily acting agent, using a sample of 150 languages. In contrast to what has been argued in earlier work, I show that the difference between IACs and their volitional, transitive counterparts is rarely situated on the level of agent case marking only. Instead, a much more common strategy for the marking of IACs involves the verb: IACs often have an anticausative instead of a regular transitive verb. I argue that anticausative verbs are used in IACs in order to represent the event as an uncontrolled event for which the involuntary agent is not responsible. Because these anticausative verbs happen to be intransitive, IACs can end up being intransitive as well. I argue, however, that this is not the result of a direct link between involuntary agents and reduced transitivity.
\end{abstract}

Keywords: Typology; Transitivity; Agency; Volitionality

\section{Introduction}

Since Hopper \& Thompson (1980), it is generally assumed that the agent of a prototypical transitive clause acts volitionally (see e.g. Tsunoda 1985, Næss 2007). Hence, clauses with a volitional agent, such as (1a), are considered to be semantically higher in transitivity than clauses such as (1b), where the agent acts involuntarily. The second type of construction is labeled here as "involuntary agent constructions” (IACs, see also Kittilä 2005, Haspelmath 1993:291-293).

(1) a. John dropped the cup.

b. John accidentally dropped the cup.

This difference in semantic transitivity is expected to correlate with morphosyntactic transitivity in at least some of the languages of the world. In comparison with regular transitive clauses, IACs are expected to be marked for reduced 
morphosyntactic transitivity. However, such constructional effects of volitionality have only recently become the subject of cross-linguistic investigation. Malchukov (2006) argues that volitionality-related effects are most likely to be situated at the level of the agent, since volitionality is an agent-related feature. As a result, IACs are expected to show reduced morphosyntactic transitivity with respect to the agent: the involuntary agent receives a special case marker that is not used with volitional agents, whereas the rest of the construction is the same as in transitive clauses. Kittilä (2005) agrees that this is a cross-linguistic strategy for the marking of IACs, but he also points out a second possibility. He argues that IACs may also be marked for reduced transitivity on the level of the verb, as they can use an intransitive instead of a transitive verb.

As the existing work on this topic is not sample-based, the purpose of this paper is to examine these claims and hypotheses from a broad cross-linguistic perspective. Is there really a strong cross-linguistic connection between IACs and reduced morphosyntactic transitivity, as has been argued by e.g. Malchukov (2006), Kittilä (2005) and Næss (2007)? The study is based on a sample of 150 languages that has been compiled to ensure genetic and areal diversity as much as possible (see the appendix). This sample is similar to the 200-language sample used in the World Atlas of Language Structures Online (Dryer \& Haspelmath 2011), but it contains only one language per genus. ${ }^{1}$ The selection of languages did not always happen fully at random: I was of course limited by the availability of reference grammars, but I also made sure to include languages which have been mentioned in the previous literature on IACs (e.g. Lezgian, Samoan, Meithei). The full list of the languages included in the sample can be found in the appendix.

On the basis of this sample, I argue that the morphosyntactic difference between IACs and their volitional counterparts is very rarely situated on the level of agent case marking only, even though Malchukov (2006) and Kittilä (2005) claim that this is a common cross-linguistic strategy. On the other hand, Kittilä's (2005) second strategy for the marking of IACs, namely the use of an intransitive verb, is attested quite often in my sample. However, I argue that not just any type of intransitive verb can be used in IACs. This is cross-linguistically only possible when the verb in question can have anticausative semantics, i.e. when it occurs in clauses where a patientive subject is affected by an event that seems to take place spontaneously, without the involvement of an instigator (e.g. The glass broke).

Apart from examining the cross-linguistic encoding of IACs, I also analyze and explain these observations from a functional perspective. I argue that the link between anticausative verbs and IACs is not coincidental, but can be explained on a semantic basis. IACs use verbs with anticausative semantics to represent the involuntarily instigated event as an event that develops in a way over which the involuntary agent has no control, and for whose outcome they are not responsible. 
Furthermore, I also argue that there is no direct correlation between IACs and reduced morphosyntactic transitivity. IACs primarily use anticausative verbs because of their uncontrolled semantics, and not because these verbs are intransitive. This hypothesis is strengthened by the observation that, in many languages, IACs use a marker associated with uncontrolled semantics, without showing a reduction in morphosyntactic transitivity.

This paper is structured as follows. In Section 2, I will present the relevant data collected from my cross-linguistic sample. In Section 3, I analyze these data and examine how they influence existing ideas on the relationship between transitivity and volitionality. Finally, Section 4 summarizes the most important conclusions and formulates suggestions for further research.

Before moving on to the discussion of the cross-linguistic data, it is necessary to clarify some terminological issues. First, I use the term "agent" in a purely semantic sense, in order to indicate the instigator of an action that affects a patient, where "instigator" is to be interpreted as a participant who initiates an action. An involuntary agent, then, is an agent who involuntarily instigates an action, and as a result affects a patient without meaning to do so. Second, the label "involuntary agent construction" is used here to indicate any type of two-participant construction where one participant can be interpreted as an involuntary agent, who involuntarily initiates an action and accidentally affects the other participant. As a result, an IAC can always be contrasted with a regular transitive clause, where a volitional agent purposefully instigates an action and affects a patient (see e.g. the pair (1a)-(1b)). Note that this implies that some volitionality-related phenomena fall outside the scope of this paper, such as the contrast between agentive and patientive intransitive subjects (e.g. He fell down on purpose vs He fell down by accident, see Donohue \& Wichmann (2008)), or the morphosyntactic coding of involuntary experiencers (see e.g. Verstraete 2011). For a more elaborate discussion on the definition of an IAC, see Kittilä (2005). Third, this paper focuses on the link between IACs and reduced morphosyntactic transitivity. Hence, the discussion is limited to types of IACs which have been claimed to show a reduction in morphosyntactic transitivity, compared to transitive clauses with a volitional agent. Such a reduction in transitivity is found when the participants of an IAC are marked differently from participants of volitional, transitive clauses, or when the verb or verbal marking is associated with intransitivity (see e.g. Kittilä 2005). Other types of IACs are excluded from the discussion, unless they are relevant for the argumentation. 


\section{IACs and reduced transitivity: data}

This section discusses two cross-linguistic types of IACs that have been claimed to show reduced transitivity. First, I discuss IACs which differ from transitive clauses in the marking of the agent only. I show that this type of IAC is very uncommon in my sample: it is rare for involuntary agents to be distinguished from their volitional counterparts by the use of a special case marker (for a similar observation with respect to inanimate agents, see Fauconnier (2011)). Second, I discuss IACs which differ from transitive clauses in the marking of the verb. These IACs, which exhibit an intransitive or detransitivized verb, are more common cross-linguistically.

\subsection{Agent case marking}

As mentioned in the introduction, both Malchukov $(2006,2008)$ and Kittilä (2005) mention that it is common for volitionality effects to occur on the level of agent marking. Involuntary agents receive a special case marker that is not used with volitional agents, whereas the marking of the verb and the patient is the same as in transitive clauses. In this section, I will show that this prediction is not borne out in my sample. There are only three possible examples of languages where IACs are exclusively marked on the agent, and in each of these cases, the analysis is not unproblematic.

The first possible example comes from the Papuan language Folopa. Anderson \& Wade (1988) cite one example where the contrast between ergative and zero marking seems to correlate with volitional versus involuntary agents. It is, however, not entirely clear if it is really a contrast in volitionality that is coded here. In all other examples, the use of the ergative marker is not a matter of volitional instigation, but of the social right to control certain actions and manipulate certain objects. In a clause like I tear off a piece of this cloth, for instance, the use of the ergative marker would indicate that the speaker is the owner of the cloth. The non-use of the ergative, on the other hand, would indicate that the speaker does not have the social right to tear the cloth, since it does not belong to him or her (Anderson \& Wade 1988:12). It may very well be that an involuntary agentreading may only arise in certain contexts as a result of pragmatic inferencing; this is at least implicitly suggested by Anderson \& Wade (1988: 12).

A second language that should be mentioned here is Meithei (or Manipuri). Meithei has been cited as a language where overt agent case marking depends on volitionality (e.g. Bhat \& Ningomba 1997, de Hoop \& Malchukov 2007), but this analysis has recently been rejected by Chelliah (2009). She argues that Meithei agent marking is related to unexpectedness rather than volitionality. 
The third language for which agent case marking has been claimed to correlate with volitionality is Samoan (Kittilä 2005:398, citing Mosel \& Hovdhaugen 1992). Again, this claim is somewhat problematic. In some Samoan clauses, the use versus non-use of the ergative marker does seem to correlate with a difference in volitionality, but according to Mosel \& Hovdhaugen (1992:424) this alternation between zero and ergative marking is only possible with cognitive verbs like 'see'. These verbs can either be used with a transitive case frame (ergative-marked agent, zero-marked patient, see the regular transitive clause in example (2a)) or with a case frame that is associated with, among other things, experiencer constructions (zero-marked experiencer, locative-marked stimulus, see example (2b)). ${ }^{2}$

Samoan (Mosel \& Hovdhaugen 1992:423,428)

(2) a. Fau loa $\varnothing$ le pà e Läulu fix then ABS ART hook ERG Läulu 'Then Läulu fixed the hook'

transitive

b. E alofa $\varnothing$ le tamai le teine GENTAM love ABS ART boy LOC ART girl 'The boy loves the girl'

experiencer

With these cognitive verbs, the transitive case frame is associated with "intention or at least a high degree of consciousness" (p.424), whereas the experiencer case frame is used for unplanned events. Thus, when a clause like the woman saw the principal has a transitive case frame, as in example (3a), this implies that the woman visited the principal, e.g. in his office. When this clause has an experiencer case frame, as in example (3b), this implies that the woman happened to see the principal, e.g. at the market.

Samoan (Mosel \& Hovdhaugen 1992: 424)

(3) a. Na va'aie le fafine $\varnothing$ le pule=äoga

PST see ERG ART woman ABS ART rule=school

'The woman saw the principal'

transitive

b. Na va'ai Ø le fafine $i$ le pule=ä’oga

PST see ABS ART woman LOC ART rule $=$ school

'The woman saw the principal'

experiencer

On the basis of these data, it seems to me that these cognitive verbs take an experiencer case frame in typical experiencer contexts, whereas they take a transitive case frame when the cognizer is not a true experiencer, but an instigator who actively initiates an action. In short, Samoan cannot be labeled as a language where volitionality is marked on the agent, because (a) differential marking (ERG vs Ø) is not available with regular transitive verbs beyond the domain of cognition, and 
(b) the contrast between agents and experiencers is different from the contrast between volitional and involuntary agents. This analysis is confirmed by Mosel (1991: 185).

Thus, neither Folopa, nor Meithei, nor Samoan qualify as unequivocal examples with special agent marking for involuntary agents. Apart from these, there are no other languages in my sample where IACs might exclusively involve agent case marking. There is the often-cited example of Lezgian, but this will be discussed in Section 2.2.2. The next subsection discusses how involuntary agents can trigger constructions where the marking of the verb is different from the prototypical transitive pattern.

\subsection{Verbal marking}

In this subsection, I discuss a cross-linguistic strategy for the marking of IACs that was identified by Kittilä (2005). According to him, IACs can have a verb that is formally less transitive than the verb of a clause with a volitional agent. The verb can, for instance, have a detransitivizing marker, or it can be lexically intransitive.

Such a phenomenon is indeed attested in my sample, but I argue that not just any type of detransitivized or intransitive verb can be used in IACs. Cross-linguistically, this is only possible when the verb in question can be associated with what I will call "anticausative semantics". A verb with anticausative semantics is defined here as a verb that can be used in a one-participant clause where a semantic patient is affected by an event that seems to happen spontaneously (see also Haspelmath 1987, Härtl 2003, Siewierska 2011). There is no participant who can be identified as the instigator of the event, or who has control over the way in which the event develops. Examples of clauses where the verb has anticausative semantics are the glass broke or the ship sank. It should be noted that this definition of anticausative semantics applies equally to derived and underived verbs, even though the term was originally reserved for derived verbs only (Nedjalkov \& Sil'nickij 1969). Also, I would like to point out that this concept of anticausative semantics is a comparative concept in the sense of Haspelmath (2010). The verbs and markers mentioned below are not always described as "anticausative" in the language-specific literature, e.g. because they can be associated with other functions as well. The label "anticausative" is used here to highlight the only function that is shared by all the verbs and markers discussed here: detransitivized and intransitive verbs are only used in IACs when they can be associated with anticausative semantics.

This subsection is divided in three parts. In 2.2.1 I discuss IACs which use a derived anticausative verb, i.e. a verb that has an overt anticausative marker. The semantic patient is the only argument of this verb, whereas the involuntary agent is expressed as an adjunct that can be entirely omitted without affecting the 
grammaticality of the clause. In 2.2.2, I discuss a similar type of IAC where the verb is an underived anticausative verb, for which the anticausative semantics is part of its lexical meaning. In 2.2.3, finally, I discuss IACs where the involuntary agent and the patient are expressed in the same way as in volitional, transitive clauses, even though the verb is a derived anticausative verb. Since these IACs exhibit a case frame that is normally found in transitive clauses and a verb that normally only occurs in intransitive clauses, Kittilä (2005) labels them as "hybrid".

Before moving on to the data, I would like to point out that the constructions discussed here are identified as IACs on the basis of information from reference grammars and/or fieldworkers. This means that these constructions have a participant who can be interpreted as an involuntary agent, who involuntarily instigates an action and accidentally affects a patient without meaning to do so. In some cases, however, the same construction can also have other functions as well, such as the expression of ability or malefactive.

\subsubsection{Derived anticausative verbs}

In languages like Guugu Yimidhirr, IACs have a derived verb that is overtly marked as anticausative. Compare the IAC from example (4a), with its volitional counterpart in (4b). Unlike in (4b), the verb 'break' in (4a) is marked with the suffix -:dhi, which has a number of different functions associated with detransitivization (reflexive, reciprocal, middle, antipassive, passive). What is most important here is that it can be used "to describe actions performed without conscious outside agency" (Haviland 1979:127), i.e. in anticausative clauses like (4c), where a semantic patient is affected by an event that seems to take place spontaneously.

Guugu Yimidhirr (Haviland 1979: 125,149)

(4) a. Ngadhun-gal galga nhanu dumbi-:dhi

1SG-ADESS spear[ABS] 2sG.GEN break-ANTIC.PST

'I accidentally broke your spear'

b. Ngayu galga nhanu dumbi

1sG.NOM spear[ABS] 2sG.GEN break.PST

'I broke your spear [on purpose]'

involuntary $A$

c. Yarrga-wibiiba dhamal wagi-:dhi

volitional $A$

boy-GEN father[ABS] foot[ABS] cut-ANTIC.PST

'The boy's father's foot got cut'

anticausative

A comparison between examples (4a) and (4c) indicates that they are basically the same construction, with the only difference that the former has an oblique-marked adjunct expressing the involuntary agent. The oblique case that is used here is the adessive, which is a spatial case marking an animate participant in whose presence the action of the verb takes place, and who is actively involved in the event (or 
will be actively involved in subsequent events) (Haviland 1979: 110). This implies that the IAC in (4a) can be more literally translated as 'your spear broke, and I was actively involved'. IACs in Guugu Yimidhirr thus involve an anticausative marker and a spatial case. The choice of the case marker does not seem surprising, since spatial cases are cross-linguistically well-known to develop into markers of demoted agents (Heine \& Kuteva 2002: 199).

A number of other languages also use anticausative morphology in IACs, but the case marker used for the involuntary agent is not always associated with agentivity. In Koasati, for instance, the dative case is used, as is illustrated in examples (5a) and (5b).

Koasati (Kimball 1991:76-77)

(5) a. Ittinsá:wa-k kaw-ká-:ci-hawa-:s branch-NOM snap.PL-ANTIC-MULT-AUD-PST

'One can hear the branches snapping all around'

anticausative

b. A:nipó-k am-onaksóh-ka-t

meat-NOM 1sG.DAT-char-ANTIC-PST

'I charred the meat by accident'

involuntary $A$

Both the anticausative construction in (5a) and the IAC in (5b) have a nominativemarked patientive subject and a verb that is marked by the anticausative ${ }^{3}$ suffix $-k a$; (5b) has a second participant marked by the dative case, who is interpreted as the involuntary causer of the event. This participant, then, is not encoded as a true agent or as a participant with whom the action originates, but rather as a maleficiary, i.e. a participant who is adversely affected by the event.

So far, we have made a distinction between two types of IACs. Both involve detransitive morphology associated with anticausatives, but in the first type the involuntary agent has a case that is associated with demoted agents (e.g. Guugu Yimidhirr), whereas the second type marks involuntary agents with the dative (e.g. Koasati). Languages with IACs of the first type include Guugu Yimidhirr (see above), Finnish (Kittilä 2005, p.c.), Mam (England 1983:199ff), Indonesian (Sneddon 1996:113-115; de Vries 1983), Puyuma (Teng 2008:180-184, see the examples in (6)), and possibly Lezgian (Haspelmath p.c.).

Puyuma (Teng 2008: 180)

(6) a. Mu-bu'utr=la na lawlaw ANTIC-stop=PRF DEF.NOM lamp

'The lamp went out'

anticausative 
b. Ku=s<in>alrem na 'aputr i, mu-dupa' dra gung 1sG.POSS $=<$ PRF $>$ plant DEF.NOM flower TOP ANTIC-step INDF.OBL ox 'The flowers I planted, they were [accidentally] stepped on by an ox' involuntary $A$

The second type of IAC is found in Koasati (see above), Eton (Van de Velde 2008: 122-123; Van de Velde p.c.), Kiowa (Watkins 1984: 112, 142-143, 149-150), Albanian (Kallulli 1999) and Spanish (Cuervo 2003: 186ff.). Georgian also belongs to the second category, but in this language IACs require a specific preverb indicating involuntary action, in addition to the presence of an anticausativized verb (Hewitt 2008:87, Hewitt 1995: 167-168, 276-277, Hewitt p.c.). In Sinhala both types of IACs are found: IACs have an anticausativized verb (see the regular anticausative clause in example (7a)) and an involuntary agent marked by either the agentive postposition atin, as in example (7b), or the dative case, as in example (7c)(Chandralal 2010:105-108; Henadeerage 2002:113ff; Inman 1993). For an analysis of the precise semantic difference between these two possibilities, see Beavers \& Zubair (2010).

Sinhala (Chandralal 2010: 152-154)

(7) a. Pingaana binduna

plate break.ANTIC.PST

'The plate broke' anticausative

b. Miniha atin pingaana binduna

3sG atin plate break.ANTIC.PST

'He unintentionally broke the plate'

involuntary $A$

c. Ranjit-ta puusa(-wa) prexge-nawa

Ranjit-DAT cat(-ACC) step_on.ANTIC-IND

'Ranjit accidentally steps on the cat' ${ }^{4}$

involuntary $A$

\subsubsection{Underived anticausative verbs}

Cross-linguistically, IACs can also use underived anticausative verbs. Again, there are two possibilities for the marking of the involuntary agent, namely the dative or a marker associated with demoted agents. An example from a language using the dative is German (Schäfer 2008:41ff); compare the intransitive clause in (8a) with the IAC in (8b). Note that the verb used in the IAC is clearly intransitive, as it cannot be used in transitive clauses like (8c). The same phenomenon also occurs in Tashelhiyt (Rapold 2010:361-362). 
German (Schäfer 2008: 42-43)

(8) a. Der Ballon zerplatzte

the[NOM] balloon[NOM] burst.PST

'The balloon popped'

anticausative

b. Ihm zerplatzte der Ballon

him.DAT burst.PST the[NOM] balloon[NOM]

'He accidentally popped the balloon'

involuntary $A$

c. ${ }^{\star}$ Er zerplatzte den Ballon

he[NOM] burst.PST the.ACC balloon[ACC]

'He popped the balloon'

volitional $A$

In the Nakh-Dagestanian language Lezgian, IACs use a lexically intransitive verb in combination with a case associated with demoted agents, namely the adelative. This can be seen in example (9). Note that here, too, the verb is intransitive and denotes a non-agentive process that can occur spontaneously (Haspelmath 1993: 292). A similar phenomenon occurs in Tsez, which is also a Nakh-Dagestanian language, but belonging to a different genus (Comrie 2000:365).

Lezgian (Haspelmath 1993: 292)

(9) Dide.di-waj nek alâx-na

mother-ADEL milk[ABS] boil_over-AOR

'Mother involuntarily allowed the milk to boil over'

involuntary $A$

In previous works, Lezgian has sometimes been cited as a language where agent case marking is the only difference between clauses with a volitional agent and clauses with an involuntary agent (e.g. Malchukov 2006, Kittilä 2005). Haspelmath (1993), however, stresses that such an analysis is incorrect. Whereas clauses with a volitional agent have a transitive verb and a patient, IACs have an intransitive, anticausative verb with a patientive subject. The problematic claim is based on a number of examples where the IAC has an ambitransitive or "labile" verb, which allows both a transitive and an intransitive valence pattern. Examples (10a) and (10b) show how the verb 'break' can be used in both intransitive clauses with a patientive subject, and in transitive clauses with an agent and a patient. As this verb can have an intransitive valence pattern in combination with anticausative semantics, it can be used in IACs like (10c).

Lezgian (Haspelmath 1993: 289,292)

(10) a. Get'e xa-na

pot[ABS] break-AOR

'The pot broke'

anticausative 
b. Zamira.di get'e xa-na

Zamira.ERG pot[ABS] break-AOR

'Zamira broke the pot'

volitional $A$

c. Zamira.di-wajget'e xa-na

Zamira.ADEL pot[ABs] break-AOR

'Zamira broke the pot accidentally/involuntarily'

involuntary $A$

Since the verb 'break' also happens to allow a transitive case frame, a comparison between the transitive, volitional clause in (10b) and the IAC in (10c) seems to suggest that the only difference lies in the marking of the agent. As a result, it has been claimed that Lezgian IACs are transitive constructions where the ergative case has been replaced with the adelative. This analysis is incorrect because IACs with an ADEL - VERB - ABS structure are only possible when the verb meets two criteria. It has to allow an intransitive case frame, and it has to be compatible with a non-agentive, anticausative reading (e.g. the intransitive verb in (9) or the ambitransitive one in (10c)). Regular transitive verbs such as $a q^{h} a j$-, 'open (tr.)' do not fulfill the criteria, and as a result they cannot be used in IACs. This is illustrated by the ungrammaticality of example (11).

Lezgian (Haspelmath 1993:292)

\section{(11) ${ }^{*}$ Taibat.a-waj rak $a q^{h}$ aj-na}

Taibat.ADEL doorABS open-AOR

'Taibat accidentally opened the door'

involuntary A (tr. verb)

This means that the IAC in (10c) should not be analyzed as a transitive clause with an absolutive-marked patient and an adelative-marked agent, but as an intransitive clause with a patientive, absolutive-marked subject and an involuntary agent in an adelative-marked adjunct NP (Haspelmath 1993:292).

Some languages can use both lexical and derived anticausative verbs in IACs. Thus, Guugu Yimidhirr does not only have IACs with derived anticausative verbs, as in example (4a), repeated below as (12a), but also allows underived anticausatives in IACs, such as the verb 'fall' in (12b). More or less the same situation is found in Finnish (Kittilä 2005, p.c.), and probably also in Lezgian (see below).

Guugu Yimidhirr (Haviland 1979: 125)
a. Ngadhun-galgalga nhanu dumbi-idhi
1sG-ADESS spear[ABS] 2sG.GEN break-ANTIC.PST
'I accidentally broke your spear'
b. Nhanu minha gundil buli ngadhun-gal
2sG.GEN meat[ABS] egg[ABS] fall.PST 1sG-ADESS
'I dropped your egg by accident'
involuntary A (underived) 


\subsection{3 "Hybrid" IACs}

Kittilä (2005:395) identifies a type of IACs which he describes as "hybrid", since it is "a combination of transitive and intransitive clauses; it has retained transitive argument marking and inherited verb morphology from an intransitive construction". Such a phenomenon is attested in my sample, but again the verb has to be associated with anticausative semantics. An example of this is found in Yidiny, a Pama-Nyungan language like Guugu Yimidhirr (Dixon 1977). In the IAC in example (13), the verb is marked with the detransitivizer -: dyi, a cognate of Guugu Yimidhirr -: dhi, which also has anticausativization as one of its uses. The involuntary agent 'man', however, has ergative marking, which normally only occurs in transitive clauses. ${ }^{5}$

Yidiny (Dixon 1977:275)

(13) Bunya wagudya-nggu gunda-:dyi-nyu bangga:l-da woman[ABS] man-ERG cut-ANTIC-PST axe-INS

'The man cut the woman accidentally with his axe'

A second example comes from Cupeño. The verbal suffix -yaxe normally transforms transitive clauses such as I broke the pot into anticausative ones such as the pot broke, as in example (14a). This same anticausative suffix is also used in IACs, but the agent and the patient are marked in the same way as in transitive clauses. This is illustrated in example (14b), where two arguments are cross-referenced on the verb, even though it is marked with -yaxe (Hill 1969).

Cupeño (Hill 1969:349-350)
a. Kevámelem cípil-pe-yaxe
pot break-3sG.s-ANTIC
'The pot shattered'

anticausative

b. ne'en pi-wecáx-ne-yaxe

1sG 3sG.P-throw.down-1sG.A-ANTIC

'I dropped it accidentally'

involuntary $A$

Madurese, a language that is related to Indonesian, allows both fully intransitive and "hybrid" IACs: the involuntary agent can be realized as either an obliquemarked adjunct or a normal transitive argument (Davies 2010:277-279). Semelai exhibits IACs which are very similar to those found in Indonesian and Madurese, probably due to contact influence from Malay, also a Western Malayo-Polynesian language. Here, however, only the "hybrid" type is attested (Kruspe 2004:140142).

A last example from a language with "hybrid" IACs is Tanacross. Tanacross IACs are similar to those found in Georgian (Section 2.2.1), in that they are not 
only characterized by the presence of an anticausative marker, but also require an additional prefix that explicitly indicates involuntary action (Holton 2000: 191192, 241, Holton p.c.).

In this section, I have discussed different types of IACs which have been claimed to show reduced morphosyntactic transitivity. I have argued that in my sample, there are no unequivocal examples of IACs which differ from their volitional counterparts in the marking of the Agent only. IACs which are marked on the level of the verb, however, are attested quite often in my sample. These IACs have an anticausative instead of a regular transitive verb. Their case frame can be both intransitive or transitive, i.e. the involuntary agent and the patient can be expressed in the same way as the agent and the patient of a transitive clause, or the patient can be the only argument of the anticausative verb, while the involuntary agent is expressed as an adjunct. When the case frame is intransitive, it seems to me that this is a result of the presence of the anticausative verb. I do not consider the intransitive case frame as a phenomenon that is independent from the use of an anticausative verb, since they are always found together: an intransitive case frame is only possible with anticausative verbs. In these cases, the anticausative verb is strongly linked with morphosyntactic intransitivity, to the effect that it can only take one single argument. As a result, I consider the use of an anticausative verb as the main characteristic of the IACs discussed here. This observation will be further explored in the next section.

\section{The relationship between IACs and reduced transitivity}

As mentioned in the introduction, many earlier works on this topic expect IACs to show reduced morphosyntactic transitivity because of the reduced semantic transitivity that is associated with involuntary agents (see e.g. Kittilä 2005, Malchukov 2006, Næss 2007:85,93-96). In this approach, which goes back to work by Hopper \& Thompson (1980), agents of prototypical transitive clauses act volitionally. Because of the reduced semantic transitivity associated with involuntary agents, IACs are expected to show reduced morphosyntactic transitivity as well (Figure 1). In this section, I will argue that the data presented above shed a different light on the relationship between involuntary agents and reduced transitivity.

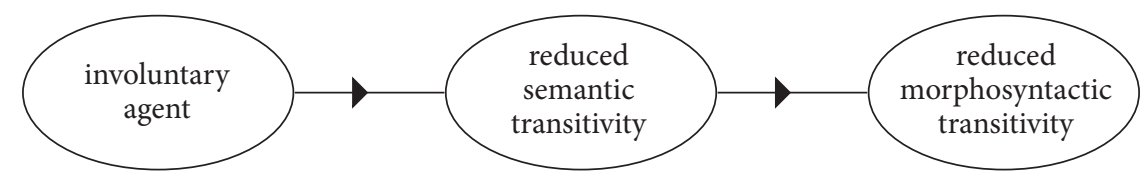

Figure 1. Existing approaches to the relationship between IACs and transitivity 
The existing approaches to IACs posit a direct link between involuntary agents and reduced transitivity. My data, however, show that IACs are not linked with reduced morphosyntactic transitivity in general, but specifically with anticausative verbs. So far, this link between IACs and anticausatives has gone largely unnoticed in the typological literature, despite a suggestion by Kittilä (2005) pointing in this direction. ${ }^{6}$ There is, however, some formally-oriented literature on the use of anticausative verbs in IACs, focusing mainly on a number of European languages, see e.g. Schäfer (2008), Kallulli (2006). In the following paragraphs, I will argue that the link between IACs and anticausative verbs is not coincidental, and that it has important implications for the correlation between IACs and reduced transitivity.

First, the use of anticausative verbs in IACs is not coincidental, because events denoted by anticausative constructions are semantically similar to events denoted by IACs in two respects. The first respect relates to the way in which the event develops. In anticausative constructions, there is no instigator participant involved, and as a result there is no participant who has any influence on, or control over, the way in which the action takes place. Likewise, IACs do not have a participant who can control the way in which the event is carried out. An involuntary agent cannot choose, for instance, to affect a patient slowly instead of quickly, or partially instead of completely. The second respect is related to the outcome of the event. The lack of an instigator in anticausative constructions also means that there is nobody who can be held responsible for the outcome of the event. A similar observation can be made for IACs. Although there is an involuntary agent who instigated the event, this involuntary agent cannot be held responsible for its outcome, since they only acted involuntarily. ${ }^{7}$ Under this account then, IACs use anticausative verbs in order to represent the involuntarily instigated event as an event that develops in a way over which the involuntary agent has no control, and for whose outcome they are not responsible. Because of these semantic similarities, I group events denoted by anticausative constructions and events denoted by IACs together under one category of "uncontrolled events" (see Figure 2). This concept of uncontrolled events is somewhat similar to Klaiman's (1991) concept of non-control.

Second, the link between IACs and anticausatives is also important for the correlation between IACs and reduced morphosyntactic transitivity. I have argued

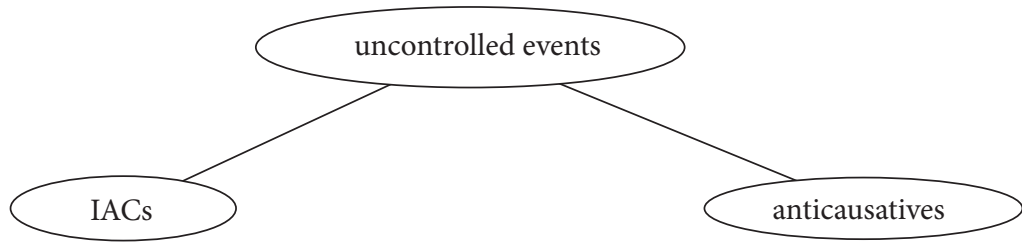

Figure 2. Anticausative constructions and IACs share "uncontrolled event" semantics 
that IACs are not linked with reduced transitivity in general, but specifically with anticausative verbs. Moreover, this phenomenon is well-motivated, since there are specific semantic links between events denoted by anticausative constructions and events denoted by IACs. As a result, it does not seem necessary to posit a direct link between involuntary agents and reduced transitivity in order to explain the formal properties of IACs. Such a link does not explain why IACs are specifically linked with anticausative verbs, and it is semantically rather vague: it assumes that prototypical transitive clauses have a volitional agent, without giving a precise semantic motivation for this. It is true that many IACs discussed in Section 2 are morphosyntactically intransitive, but this does not necessarily mean that there is a direct link between the two. Instead, I argue that the link between IACs and morphosyntactic intransitivity is only indirect. As argued above, IACs tend to use anticausative verbs because these verbs are associated with uncontrolled semantics. These anticausative verbs are morphosyntactically intransitive, because they normally denote one-participant events. As a result, the IACs that use these verbs can end up being intransitive as well. Put differently, there is a direct link between IACs and anticausatives on the one hand, and between anticausatives and intransitivity on the other hand, but not between IACs and intransitivity (Figure 3).

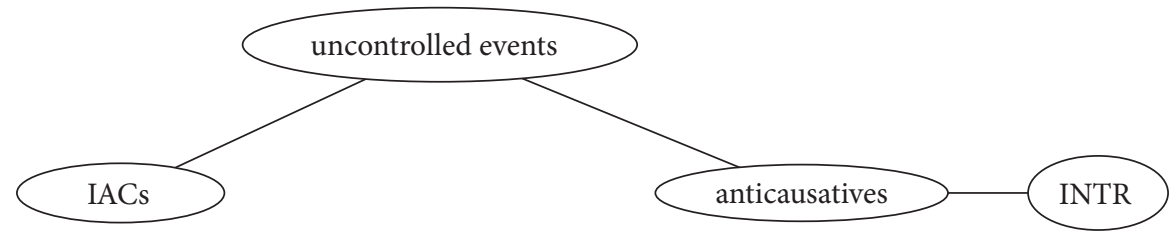

Figure 3. IACs are only indirectly linked to intransitivity

This approach, then, primarily links IACs with uncontrolled events and anticausatives, and only indirectly with intransitivity. IACs use anticausative verbs because of their uncontrolled event semantics, and the intransitivity of these verbs incidentally carries over to IACs. If this view is correct, it is expected that the morphosyntactic features of at least some IACs might be associated with uncontrolled events, without necessarily showing reduced morphosyntactic transitivity. The following four phenomena show that this prediction is borne out in my sample.

The first phenomenon is the occurrence of the "hybrid" IACs, described in Section 2.2.3. These constructions have a transitive case frame, even though the verb has anticausative morphology, which normally has a detransitivizing effect (see the Yidiny example in (13)). Under my approach, such a phenomenon is expected. IACs primarily use anticausative morphology because of its association with uncontrolled event semantics, and not because of its association with reduced transitivity. As a result, the verbal morphology used in IACs may lose its 
association with morphosyntactic intransitivity, resulting in the use of a transitive case frame.

Second, the Salishan language St'át'imcets (or Lillooet) illustrates how the morphology used in IACs can be associated with uncontrolled event semantics, without being linked with intransitivity. This language has so-called "out-of-control" (OC) morphology, viz. the circumfix ka-...-a. As illustrated in example (15a), this morpheme can have anticausative semantics. The circumfix can also be used in IACs to encode involuntary instigation, and in certain modal contexts. Crucially, however, it is not associated with detransitivization in any way (Davis et al. 2009).

St'át'imcets (Davis et al. 2009:212-213)
a. Ka-lhót-a
aylh $i=s 7 a y^{\prime} t s q w=a$
nilh
OC-get.squished-oc then PL.DET=raspberry=EXIS FOC
$k a-t e ́ q w=s-a \quad t i=n-t s q-u ́ s-t n=a$
oC-dent $=3$ POSS-OC DET $=$ LOC-put.down-face-thing $=$ EXIS
'The raspberries got squished and the pot got dented'

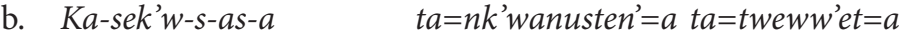
oc-break-CAUS-3ERG-OC DET=window=EXIS DET=boy=EXIS
'The boy broke the window accidentally'

The third phenomenon that I will discuss here shows that even transitivizing morphology can be used in IACs. In Mapudungun (or Mapuche), it is possible with some verbs to form an IAC using the causative morpheme $-l$. This morpheme has a transitivizing function, adding an agent to the argument structure of the verb. Normally, clauses with such a causativized verb have a volitional reading, but with some verbs the use of the $-l$ causative explicitly signals involuntary action. Thus, wacho-means 'to break', whereas the causative wacho-l-means 'to break unintentionally' (Smeets 2008:299-300; Zúñiga 2010:213, p.c.). This phenomenon is difficult to account for under existing approaches to involuntary action, but can be better understood under the approach I advocate here. Crucially, the verbs that receive an involuntary reading when causativized are ambitransitive verbs (Zúñiga 2010:213). They can denote both intransitive, uncontrolled events, in which case they take a patientive subject, and regular transitive events, in which case they take an agent and a patient: 'break (intr.)' vs 'break (tr.)', 'loosen (intr.)' vs 'loosen (tr.)' and 'become wet' vs 'make wet.' For these verbs, there is no need for a derived causative form, since the causative can already be expressed using the underived form. As a result, the causative morpheme becomes available for another function. Instead of transforming an intransitive verb into a regular transitive one, it simply adds an instigator participant to the verb, while leaving its uncontrolled semantics 
untouched. The derived verb, then, has two arguments and is associated with uncontrolled semantics, which results in an involuntary agent-reading.

The last phenomenon shows that even languages with intransitive IACs (as described in Sections 2.2.1 and 2.2.2) can allow IACs to be construed on the basis of a regular transitive clause, provided that this clause has uncontrolled event semantics. Lezgian, for instance, forms IACs by adding an adelative-marked involuntary agent to any clause denoting an uncontrolled event (Haspelmath 1993:293). As illustrated in Section 2.2.2, this can be a clause with a lexically intransitive verb associated with anticausative semantics (example (9), repeated as (16) below). There are, however, also other types of clauses that denote uncontrolled events, which are available for use in IACs. Thus, IACs can involve periphrastic constructions with the verb 'to happen' (Haspelmath 1993:91), and probably also transitive verbs with anticausative morphology (Haspelmath p.c.). Crucially, however, it is even possible for a fully transitive clause with two arguments to be used in an IAC, as long as this clause expresses an uncontrolled event. This is illustrated by example (17). This example exhibits a fully transitive clause, 'the curtain caught fire', with an ergative-marked agent 'curtain' and an absolutive-marked patient 'fire'. Since this clause denotes an uncontrolled event (it is instigated by an inanimate agent), it is possible to add an adelative-marked involuntary agent 'mother' in order to form an IAC. ${ }^{8}$

Lezgian (Haspelmath 1993: 292-293)

Dide.di-waj nek alâx-na
mother-ADEL milk[ABs] boil_over-AOR

'Mother involuntarily allowed the milk to boil over'

(17) Dide.di-waj perde.di c’aj q’u-na

mother-ADEL curtain.ERG fire[ABS] catch-AOR

'Mother accidentally caused the curtain to catch fire'

Summing up, there is considerable evidence that the correlation between involuntary agents and reduced morphosyntactic transitivity is only indirect. IACs are often intransitive, but this is only an epiphenomenon. What is most important is that IACs prefer to use morphology or verbs that are associated with uncontrolled events. IACs can end up being intransitive when the source morphology or the source verb happens to be intransitive, as is the case with anticausatives, but this is not necessarily the case, and it is not a direct consequence of the presence of an involuntary agent. 


\section{Conclusion and outlook}

In this paper, I have examined cross-linguistic data on IACs on the basis of a crosslinguistic sample of 150 languages. I have shown that there are no uncontroversial instances of languages where IACs differ from their volitional counterparts only in the marking of the agent. Instead, IACs are often characterized by the use of anticausative verbs, i.e. verbs that can be used in a one-participant clause where a semantic patient is affected by an event that seems to happen spontaneously. I have argued that this link between IACs and anticausatives is not coincidental, since they share what I have called "uncontrolled event" semantics. Both IACs and anticausatives express events that develop in a spontaneous, uncontrolled way, for which nobody can be held responsible.

These findings have important implications for the association between IACs and reduced morphosyntactic transitivity. Claims about a direct correlation between involuntary agents and reduced transitivity are abundant in the literature since Hopper \& Thompson (1980), but in this paper I have argued that the presence of an involuntary agent does not directly lead to reduced morphosyntactic transitivity. Instead, constructions with such an agent use anticausative verbs because of shared semantics, and the intransitivity of these verbs might incidentally carry over to the IACs.

The work presented in this paper may not only lead us to to rethink the association between involuntary agents and reduced transitivity, but it also raises questions about the level at which volitionality is relevant. Traditionally, volitionality is considered as a semantic feature of the prototypical agent (see e.g. Dowty 1991, Næss 2007). Hence, it is expected that a deviation in volitionality leads to formal marking on the agent itself (see e.g. Malchukov (2006), whose "relevance principle" predicts that transitivity features are usually marked on the relevant constituent). In this paper, however, I have shown that it is uncommon for IACs to be marked at the level of the agent only. Instead, IACs are marked on the level of the verb. Moreover, the analysis offered in Section 3 explains the link between anticausatives and IACs on the basis of event semantics: anticausative verbs are used in IACs because they are associated with uncontrolled events. There are thus indications that volitionality is in fact not an agent-level feature, but a feature that is relevant on the level of the entire event. What matters is not the properties of the agent, but the way in which the event develops or is seen to develop. ${ }^{9}$ This hypothesis is in line with earlier work by Van Valin \& Wilkins (1996), who argue that volitionality is not a crucial feature of agents.

Another subject for further research could be to investigate how volitionality effects in two-participant clauses, which were examined in this paper, compare with effects in one-participant clauses. There are a number of languages in my 
sample where subject case marking does seem to be the only difference between clauses such as He fell down on purpose and He fell down accidentally, e.g. Eastern Pomo (McLendon 1975) and Klon (Baird 2008) (see also Donohue \& Wichmann 2008, de Hoop \& Malchukov 2007). This suggests an interesting difference with volitionality effects in transitive clauses, which are rarely situated on the level of the agent only.

Finally, there are languages in my sample that indicate that the marking of IACs is not always associated with anticausatives or uncontrolled events. Japanese and Malayalam, for instance, can express involuntary actions by using a completive auxiliary (Ono 1992, Asher \& Kumari 1997). While this is further confirmation that IACs are not necessarily associated with reduced morphosyntactic transitivity, it also suggests that there is a possible source of marking of IACs that has been overlooked in the typological literature. It remains to be investigated how the semantics of involuntary actions is linked with completive aspect, and how this type of IAC can be incorporated in the existing typology.

\section{Acknowledgments}

An earlier version of this paper was presented at the 85th Annual Meeting of the Linguistic Society of America in Pittsburgh, January 6-9 2011. I would like to thank Jean-Christophe Verstraete, Balthasar Bickel and two anonymous reviewers for their careful reading of earlier drafts. The paper benefited significantly from their extensive and useful comments. I am also very grateful to many fellow researchers who took the time to discuss language-specific data with me, in particular Martin Haspelmath, George Hewitt, Gary Holton, Seppo Kittilä, Mark Van de Velde and Fernando Zuñiga. Of course, responsibility for any remaining inaccuracies or mistakes is entirely my own. This research was funded by the project "Optional ergative marking and the architecture of case systems" (OT/08/011, Research Council of the University of Leuven). Part of it was carried out during a research stay at the University of California, Berkeley, funded by the Research Foundation Flanders (FWO Vlaanderen) and the Academische Stichting Leuven.

\section{Notes}

1. Pama-Nyungan is represented by two languages (Yidiny and Guugu Yimidhirr) because of interesting differences between IACs.

2. Examples are glossed according to the Leipzig Glossing Rules. Abbreviations not in the Leipzig Glossing Rules are: ADEL adelative, ADESS adessive, ANTIC anticausative, AOR aorist, AUD auditory, EXIs existential, GENTAM general tense-aspect-mood marker, MULT multiplicative, OC out-of-control. Round brackets indicate that the morpheme is optional. 
3. Kimball (1991:76) labels this suffix as mediopassive, but it has no other functions besides marking anticausatives, as in (5a), where "the action apparently occurs without the intervention of an agent", and IACs, as in (5b).

4. In this example, the patient "cat" can optionally take accusative case marking. This is because accusative case marking is available for all animates which are semantic patients, even in oneparticipant clauses with an anticausative verb, such as $(7 \mathrm{a})$.

5. Note that there is no ergative-instrumental syncretism in Yidiny, unlike in many other PamaNyungan languages (Dixon 1977: 128).

6. Shibatani (2006) argues that voice can be used to encode the contrast between volitional and involuntary actions, but he does not mention the connection with anticausatives.

7. Note that this concept of responsibility should be interpreted as moral responsibility, and not as causal responsibility (see e.g. Eshleman 2009).

8. Note that the adelative-marked involuntary agent does not replace the ergative-marked agent. As argued above (see example (11)), this is not possible in Lezgian. Instead, the involuntary agent is added as an adjunct NP.

9. The idea that the difference between volitional and involuntary actions mainly lies in the way the event develops is also present in work by Shibatani (2006).

\section{References}

Anderson, Neil \& Martha Wade. 1988. Ergativity and control in Folopa. Language and Linguistics in Melanesia 19. 1-16.

Asher, Ronald E. \& T. C. Kumari. 1997. Malayalam. London: Routledge.

Baird, Louise. 2008. A grammar of Klon: A non-Austronesian language of Alor, Indonesia. Canberra: Pacific Linguistics.

Beavers, John \& Cala Zubair. 2010. The interaction of transitivity features in the Sinhala involitive. In Patrick Brandt \& Marco García García (eds.), Transitivity: Form, meaning, acquisition, and processing, 69-94. Amsterdam: John Benjamins.

Bhat, Darbe N.S. \& M.S. Ningomba. 1997. Manipuri grammar. München: Lincom Europa.

Chandralal, Dileep. 2010. Sinhala. Amsterdam: John Benjamins.

Chelliah, Shobhana. 2009. Semantic role to new information in Meithei. In Jóhanna Barðdal \& Shobhana Chelliah (eds.), The role of semantic, pragmatic, and discourse factors in the development of case, 377-400. Amsterdam: John Benjamins.

Comrie, Bernard. 2000. Valency-changing derivations in Tsez. In Robert M.W. Dixon \& Alexandra Y. Aikhenvald (eds.), Changing valency. Case studies in transitivity, Cambridge: Cambridge University Press.

Cuervo, Maria Cristina. 2003. Datives at large: Massachusetts Institute of Technology dissertation.

Davies, William D. 2010. A grammar of Madurese. Berlin: Mouton de Gruyter.

Davis, Henry, Lisa Matthewson \& Hotze Rullmann. 2009. 'Out of control' marking as circumstantial modality in St'át'imcets. In Lotte Hogeweg, Helen de Hoop \& Andrej Malchukov 
(eds.), Cross-linguistic semantics of tense, aspect, and modality, 205-244. Amsterdam: John Benjamins.

Dixon, Robert M.W. 1977. A grammar of Yidiny. Cambridge: Cambridge University Press.

Donohue, Mark \& Søren Wichmann (eds.). 2008. The typology of semantic alignment. Oxford: Oxford University Press.

Dowty, David. 1991. Thematic proto-roles and argument selection. Language 67(3). 547-619.

Dryer, Matthew S. \& Martin Haspelmath (eds.). 2011. The World Atlas of Language Structures Online. Munich: Max Planck Digital Library. http://wals.info. Accessed on 2011-05-02.

England, Nora C. 1983. A grammar of Mam, a Mayan language. Austin: University of Texas Press. Eshleman, Andrew. 2009. Moral responsibility. In Edward N. Zalta (ed.), The Stanford encyclopedia of philosophy (winter 2009 edition), http://plato. stanford.edu/archives/win2009/entries/ moral-responsibility. Accessed on April 262011.

Fauconnier, Stefanie. 2011. Differential Agent Marking and animacy. Lingua 121. 533-547.

Härtl, Holden. 2003. Conceptual and grammatical characteristics of argument alternations: The case of decausative verbs. Linguistics 41(5). 883-916.

Haspelmath, Martin. 1987. Transitivity alternations of the anticausative type. Cologne: Institut für Sprachwissenschaft der Universität zu Köln.

Haspelmath, Martin. 1993. A grammar of Lezgian. Berlin: Mouton de Gruyter.

Haspelmath, Martin. 2010. Comparative concepts and descriptive categories in crosslinguistic studies. Language 86(3). 663-687.

Haviland, John. 1979. Guugu Yimidhirr. In Robert M.W. Dixon \& Barry J. Blake (eds.), Handbook of Australian languages. Volume 1,27-180. Amsterdam: John Benjamins.

Heine, Bernd \& Tania Kuteva. 2002. World lexicon of grammaticalization. Cambridge: Cambridge University Press.

Henadeerage, Deepthi Kumara. 2002. Topics in Sinhala syntax: Australian National University dissertation.

Hewitt, George. 1995. Georgian: A structural reference grammar. Amsterdam: John Benjamins.

Hewitt, George. 2008. Cases, arguments, verbs in Abkhaz, Georgian and Mingrelian. In Greville Corbett \& Michael Noonan (eds.), Case and grammatical relations: Studies in honor of Bernard Comrie, 75-104. Amsterdam: John Benjamins.

Hill, Jane. 1969. Volitional and non-volitional verbs in Cupeño. Papers from the meeting of the Chicago Linguistic Society 4. 348-356.

Holton, Gary. 2000. The phonology and morphology of the Tanacross Athabaskan language: University of California, Santa Barbara dissertation.

de Hoop, Helen \& Andrej Malchukov. 2007. On fluid differential case marking: A bidirectional OT approach. Lingua 117(9). 1636-1656.

Hopper, Paul J. \& Sandra A. Thompson. 1980. Transitivity in grammar and discourse. Language 56. 251-299.

Inman, Michael V. 1993. Semantics and pragmatics of Colloquial Sinhala involitive verbs: Stanford University dissertation.

Kallulli, Dalina. 1999. Non-active morphology in Albanian and event (de)composition. In István Kenesei (ed.), Crossing boundaries. Advances in the theory of Central and Eastern European languages, 263-292. Amsterdam: John Benjamins.

Kallulli, Dalina. 2006. Unaccusatives with dative causers and experiencers: A unified account. In Daniel Hole, André Meinunger \& Werner Abraham (eds.), Datives and other cases, 271301. Amsterdam: John Benjamins.

Kimball, Geoffrey D. 1991. Koasati grammar. Lincoln: University of Nebraska Press. 
Kittilä, Seppo. 2005. Remarks on involuntary agent constructions. Word 56(3). 381-419.

Klaiman, Miriam H. 1991. Grammatical voice. Cambridge: Cambridge University Press.

Kruspe, Nicole. 2004. A grammar of Semelai. Cambridge: Cambridge University Press.

Malchukov, Andrej. 2006. Transitivity parameters and transitivity alternations: Constraining co-variation. In Leonid Kulikov, Andrej Malchukov \& Peter de Swart (eds.), Studies on case, valency and transitivity, 329-359. Amsterdam: John Benjamins.

Malchukov, Andrej. 2008. Animacy and asymmetries in differential case marking. Lingua 118(2). 203-221.

McLendon, Sally. 1975. A grammar of Eastern Pomo. Berkeley: University of California Press.

Mosel, Ulrike. 1991. Transitivity and reflexivity in Samoan. Australian Journal of Linguistics 11(2). 175-194.

Mosel, Ulrike \& Even Hovdhaugen. 1992. Samoan reference grammar. Oslo: Scandinavian University Press.

Næss, Åshild. 2007. Prototypical transitivity. Amsterdam: John Benjamins.

Nedjalkov, Vladimir P. \& Georgij G. Sil'nickij. 1969. Tipologija morfologičeskogo i leksiceskogo kauzativov. In Aleksandr A. Xolodovič (ed.), Tipologija kauzativnyx konstrukcij. morfologičeskij kauzativ, Leningrad: Nauka.

Ono, Tsuyoshi. 1992. The grammaticization of the Japanese verbs oku and shimau. Cognitive Linguistics 3(4). 367-390.

Rapold, Christian J. 2010. Beneficiary and other roles of the dative in Tashelhiyt. In Fernando Zúñiga \& Seppo Kittilä (eds.), Benefactives and malefactives: Typological perspectives and case studies, 351-376. Amsterdam: John Benjamins.

Schäfer, Florian. 2008. The syntax of (anti-)causatives. External arguments in change-of-state contexts. Amsterdam: John Benjamins.

Shibatani, Masayoshi. 2006. On the conceptual framework for voice phenomena. Linguistics 44(2). 217-269.

Siewierska, Anna. 2011. Passive constructions. In Matthew S. Dryer \& Martin Haspelmath (eds.), The World Atlas of Language Structures Online, Munich: Max Planck Digital Library. http://wals.info/feature/107. Accessed on 2011-05-02.

Smeets, Ineke. 2008. A grammar of Mapuche. Berlin: Mouton de Gruyter.

Sneddon, James Neil. 1996. Indonesian. A comprehensive grammar. London: Routledge.

Teng, Stacy Fang-Ching. 2008. A reference grammar of Puyuma: an Austronesian language of Taiwan. Canberra: Pacific linguistics.

Tsunoda, Tasaku. 1985. Remarks on transitivity. Journal of Linguistics 21(2). 385-396.

Van Valin, Robert D. \& David P. Wilkins. 1996. The case for 'Effector': Case roles, Agents, and agency revisited. In Masayoshi Shibatani \& Sandra A. Thompson (eds.), Grammatical constructions. their form and meaning, 289-322. Oxford: Clarendon Press.

Van de Velde, Mark. 2008. A grammar of Eton. Berlin: Mouton de Gruyter.

Verstraete, Jean-Christophe. 2011. Experienced action constructions in Umpithamu: involuntary experience, from bodily processes to externally instigated actions. Cognitive Linguistics 22. 275-302.

de Vries, Lourens. 1983. Three passive-like constructions in Indonesian. In Simon Dik (ed.), Advances in Functional Grammar, 155-173. Dordrecht: Foris Publications.

Watkins, Laurel J. 1984. A grammar of Kiowa. Lincoln: University of Nebraska Press.

Zúñiga, Fernando. 2010. Benefactive and malefactive applicativization in Mapudungun. In Fernando Zúñiga \& Seppo Kittilä (eds.), Benefactives and malefactives: Typological perspectives and case studies, 203-218. Amsterdam: John Benjamins. 


\section{Appendix: 150-language sample}

Languages are listed per family and, where applicable, genus, according to the World Atlas of Language Structures Online (Dryer \& Haspelmath 2011). To avoid an unnecessarily long bibliography, full references are not included.

Afro-Asiatic

Berber Tashelhiyt (Rapold 2010)

Biu-Mandara Hdi (Frajzyngier 2002)

West Chadic Hausa (Jaggar 2001; Heide 1989)

Eastern Cushitic Dhaasanac (Tosco 2001)

Semitic Maltese (Borg \& Azzopardi-Alexander 1997)

Southern Cushitic Iraqw (Mous 1993)

Ainu

Ainu (Tamura 2000)

Algic

Algonquian Blackfoot (Frantz 1991)

Altaic

Mongolic Mangghuer (Slater 2003)

Tungusic Udihe (Nikolaeva \& Tolskaya 2001)

Turkic Turkish (Göksel \& Kerslake 2005)

Arauan

Jarawara (Dixon 2005)

Araucanian

Mapudungun (Smeets 2008)

Arawakan

Tariana (Aikhenvald 2003)

Australian

Bunuban Gooniyandi (McGregor 1990)

Gaagudju Gaagudju (Harvey 2002)

Gunwinygic Bininj Gun-wok (Evans 2003)

Mangarrayi Mangarrayi (Merlan 1982)

Pama-Nyungan Guugu Yimidhirr (Haviland 1979), Yidiny (Dixon 1977)

Tangkic Kayardild (Evans 1995)

West Barkly Jingulu (Pensalfini 2003)

Austro-Asiatic

Aslian Semelai (Kruspe 2004)

Bahnaric Sre (Manley 1971)

Munda Mundari (Cook 1965)

Palaung-Khmuic Khmu (Svantesson 1983)

Viet-Muong Vietnamese (Nguyễn 1997)
Austronesian

Central Malayo-Polynesian Tetun (van Klinken 1999)

Malayic Indonesian (Sneddon 1996)

Madurese Madurese (Davies 1999)

Oceanic Samoan (Mosel \& Hovdhaugen 1992)

Paiwanic Amis (Joy Wu 2006)

Puyuma Puyuma (Teng 2008)

South Halmahera - West New Guinea

Warembori (Donohue 1999b)

Sulawesi Tukang Besi (Donohue 1999a)

Aymaran

Aymara (Hardman 2001)

Barbacoa

Awa Pit (Curnow 1997)

Basque

Basque (Hualde \& de Urbina 2003)

Border

Imonda (Seiler 1985)

Burushaski

Burushaski (Munshi 2006)

Cariban

De'kwana (Hall 1988)

Chapacura-Wanham

Wari' (Everett \& Kern 1997)

Chibchan

Aruak Ika (Frank 1985)

Choco

Epena Pedee (Harms 1994)

Chukotko-Kamchatkan

Northern Chukotko-Kamchatkan Chukchi (Dunn 1999)

Dravidian

Southern Dravidian Malayalam (Asher \& Kumari 1997)

East Bird's Head

East Bird's Head Meyah (Gravelle 2004)

Eskimo-Aleut

Eskimo Tunumiisut (Mennecier 1995) 
Haida

Haida (Enrico 2003)

Hmong-Mien

Hmong Njua (Lyman 1979; Harriehausen 1990)

Hokan

Pomoan Eastern Pomo (McLendon 1975)

Yuman Jamul Tiipay (Miller 2001)

Indo-European

Albanian Albanian (Kallulli 1999)

Armenian Eastern Armenian (DumTragut 2009)

Germanic German (Schäfer 2008)

Indic Sinhala (Chandralal 2010)

Romance Spanish (Cuervo 2003)

Iroquoian

Northern Iroquoian Wyandot (Kopris 2001)

Japanese

Japanese (Kaiser et al. 2001)

Jivaroan

Aguaruna (Overall 2007)

Kadugli

Krongo (Reh 1985)

Kartvelian

Georgian (Hewitt 1995)

Keresan

Laguna Keres (Lachler 2006)

Khoisan

Central Khoisan Khoekhoe (Hagman 1973)

Kiowa-Tanoan

Kiowa (Watkins 1984)

Korean

Korean (Sohn 1999)

Kuot

Kuot (Lindström 2002)

Kusunda

Kusunda (Watters 2006)

Kwaza

Kwaza (van der Voort 2004)

Solomons East Papuan

Lavukaleve Lavukaleve (Terrill 2003)

Savosavo Savosavo (Wegener 2008)

Lower Sepik-Ramu

Lower Sepik Yimas (Foley 1991)
Macro-Ge

Bororo Bororo (Crowell 1979)

Mayan

Mam (England 1983)

Mixe-Zoque

San Miguel Chimalapa Zoque (Johnson 2000)

Mosetenan

Mosetén (Sakel 2003)

Movima

Movima (Haude 2006)

Muskogean

Koasati (Kimball 1985)

Nadahup

Hup (Epps 2008)

Na-Dene

Athapaskan Tanacross (Holton 2000)

Nakh-Daghestanian

Avar-Andic-Tsezic Tsez (Comrie 2000)

Lezgic Lezgian (Haspelmath 1993)

Nambikuaran

Sabane (Antunes de Araujo 2004)

Niger-Congo

Adamawa Mundang (Elders 1995)

Bantoid Eton (van de Velde 2008)

Gur Supyire (Carlson 1994)

Kwa Fongbe (Lefebvre \& Brousseau 2002)

Southern Atlantic Kisi (Childs 1995)

Western Mande Jalonke (Lüpke 2005)

Nilo-Saharan

Fur Fur (Jakobi 1990)

Moru-Ma'di Ma'di (Blackings \& Fabb 2003)

Nilotic Turkana (Dimmendaal 1982)

Songhay Koyra Chiini (Heath 1999)

Surmic Murle (Arensen 1982)

other

Creoles and Pidgins Nubi (Wellens 2003)

Oto-Manguean

Chinantecan Sochiapan Chinantec (Foris 2000)

Mixtecan Chalcatongo Mixtec (Macaulay 1996)

Zapotecan Coatlán-Loxicha Zapotec

(Beam de Azcona 2004)

Panoan

Shipibo-Konibo (Valenzuela 2003) 
Peba-Yaguan

Yagua (Payne 1985)

Penutian

Sahaptian Nez Perce (Rude 1985)

Wintuan Wintu (Pitkin 1984)

Puinave

Wansojot (Higuita 2008)

Quechuan

Imbabura Quechua (Cole 1985)

Salishan

Interior Salish Lillooet (van Eijk 1997)

Senagi

Menggwa Dla (de Sousa 2006)

Sepik

Ram Awtuw (Felman 1986) Sepik Hill

Alamblak (Bruce 1984)

Sino-Tibetan

Bodic Kham (Watters 2002)

Burmese-Lolo Lahu (Matisoff 1973)

Chinese Cantonese (Matthews \& Yip 1994)

Karen Eastern Kayah Li (Solnit 1997)

Kuki-Chin Meithei (Chelliah 1997)

Lepcha Lepcha (Plaisier 2007)

Qiangic Qiang (LaPolla 2003)

Siouan

Assiniboine (Cumberland 2005)

Tacanan

Cavineña (Guillaume 2004)

Tai-Kadai

Lao (Enfield 2007)

Teberan-Pawaian

Teberan Folopa (Anderson \& Wade 1988)

Tequistlatecan

Highland Chontal (Turner 1966)

Timor-Alor-Pantar

Greater Alor Klon (Baird 2008)

Totonacan

Misantla Totonac (MacKay 1999)

Trans-New Guinea

Angan Menya (Whitehead 2004)

Awju-Dumut Korowai (van Enk \& de Vries 1997)

Dani Lower Grand Valley Dani (Bromley 1981)
Eastern Highlands Hua (Haiman 1980)

Madang Tauya (MacDonald 1990)

Trumai

Trumai (Guirardello 1999)

Tucanoan

Guanano (Stenzel 2004)

Tupian

Arikem Karitiana (Storto 1999)

Tupari Mekens (Galucio 2001)

Tupi-Guaraní Tapiete (González 2005)

Uralic

Finnic Finnish (Kittilä 2005, p.c.)

Ugric Hungarian (Szent-Iványi 1995)

Urarina

Urarina (Olawsky 2006)

Uto-Aztecan

Aztecan Pipil (Campbell 1985)

Cahita Yaqui (Guerrero-Valenzuela 2005)

Numic Paiute (Thornes 2003)

Takic Cupeño (Hill 1969)

Tarahumaran Warihío (Armendáriz 2005)

Wakashan

Southern Wakashan Nuuchahnulth (Davidson 2002)

Wappo-Yukian

Wappo Wappo (Thompson et al. 2006)

Warao

Warao (Romero-Figueroa 1997)

West Papuan

North Halmaheran Tidore (van Staden 2000)

North-Central Bird's Head Maybrat (Dol 2007)

Yanomam

Yanomam Sanuma (Borgman 1990)

Yeniseian

Ket (Vajda 2004)

Yuchi

Yuchi (Linn 2001)

Yukaghir

Kolyma Yukaghir (Maslova 2003)

Yuracare

Yurakare (van Gijn 2006) 


\section{Address}

Stefanie Fauconnier

University of Leuven

Blijde-Inkomststraat 21

PO box 3308

BE-3000 Leuven

Belgium

stefanie.fauconnier@arts.kuleuven.be 